\title{
Guidelines to Strengthen Positive Attitudes Towards Study at University Education
}

\author{
Derling José Mendoza \\ Dr. in Mathematics, Researcher, \\ Universidad Iberoamericana del Ecuador, Ecuador \\ Derling Isaac Mendoza \\ Student, \\ Giordano Bruno, Ecuador \\ Enderson José Mendoza \\ Professor, \\ Universidad Iberoamericana del Ecuador, Ecuador
}

Doi: $10.2478 / \mathrm{mjss}-2018-0111$

\begin{abstract}
This study focuses on the importance of implementing guidelines to strengthen positive attitudes towards the study among students at Universidad Iberoamericana del Ecuador (UNIB.E). The teaching action-research was used to respond to the situation detected. Twenty-two students were the key informants. The information was also collected through the observation and survey process, which revealed technical difficulties in maintaining interest in the study. In this order of ideas, they are considered necessary the different processes framed in the planning and execution of diverse strategies that project the motivation towards the study. In the development of the different actions applied, it is carried out an evaluation to measure the achievements obtained in order to give greater objectivity and productivity in the fulfillment of the objectives proposed in the present study. Therefore, it is clear that the apathy of students for academic activities is due to the lack of appropriate strategies because these are not meaningful to them. That means, they do not awaken the motivation to generate the necessary interest to develop positive attitudes towards the study.
\end{abstract}

Keywords: Actions, Attitudes, Study, Higher Education

\section{Introduction}

For the teaching and learning process to be effective, study orientation must be elementary. On this point, it should be assumed as a continuous process, for the formation and development of habits. The action of participatory andragogy cannot be limited to the simple transmission of knowledge, although this process is brilliant (Llorens, 2013). It is necessary to ensure that students use different working methods and procedures, with which they can perform and approach different sources of knowledge.

The learning of the different subjects of the university degrees must be supported by different elements from which the essence of the contents can be assimilated. This way the diversity of facts or phenomena studied are found. This is the reason why it is elementary that the university institution in its educational action has a wide cultural horizon (Abero et al, 2015). Therefore, for the 
study proposal to be possible, it is necessary to formulate adequate and wide reasons for the study. According to Mendoza (2018) using different strategies in education, students may feel the need to study, experience satisfaction and emotions in the search for answers. In addition, the students feel convinced. For the author this is one of the ways in which they contribute to plan their preparation.

The teacher should not only be a mentor, but also a promoter. Bruns \& Luque (2014) mention that teachers must promote their professional development and enrich their intelligence. In this way it is possible to exceed increasingly important objectives in the quality of its academic preparation and training.

The success of the student depends to a great extent on the development of an attitude towards the study. Teachers also have an important role to play in this regard. The teacher must provide tools that are sufficiently motivating to encourage the student's interest in studying (Rossi, 2014). Therefore, it is necessary to guide and direct educational actions. Apply a wide variety of strategies, methods and means to foster attitudes towards a specific activity for each student to be an active participant in his or her own learning.

In this way, the range of possibilities that exist for students to assume the study in an interesting and attractive way is notorious. Students should be enlightened by good ideas, feelings of creation, beauty, strategy, curiosity and greed for knowledge. Only that way they will develop the inherent qualities and abilities of the human being (Rodríguez et al, 2014).

Consequently, for Dalmau et al, (2002), where there is not eagerness to know and universal thought, there is not university. For the authors, the university professors express the need for constant activities to strengthen and project the interest in studying, but without tension. Achieving the enjoyment of what you want to remember for a long time, as a higher education technique.

Within this framework, this research aims to implement actions to strengthen positive attitudes towards study among UNIBE students. In the same way, for the development of the study, the research-action participant is used to execute the different steps that are immersed in it, and thus to be able to elaborate alternative solutions to the described problems.

\subsection{General Objective}

- To implement guidelines to strengthen positive attitudes towards the study, among students at Universidad Iberoamericana del Ecuador UNIB.E.

\subsection{Specific Objectives}

- To diagnose the factors that influence the low performance of UNIB.E students.

- To determine the actions which motivate the student towards positive attitudes in the strengthening of the study process.

- To develop meaningful actions to help students acquire study habits.

- To evaluate the actions which strengthen the study in the students of UNIB.E.

- To systematize the processes executed to strengthen the study of the students of the institution described before.

\subsection{Study as a relevant element in the teaching-learning process}

The systematic and constant approach of Otxandorena (2010) explains it as interactions, in relational connectivity, trying to contextualize and teach from a broader perspective, which allows us to understand the mechanisms that keep behaviors. The author takes into account the role of the teacher within the system, facilitating the educator to intervene on the multiple aspects that make up the system. López (2009) states that the work of the university and each professor must be oriented and organized. He also points out in his texts that a motivational consolidation towards the study must be guaranteed. In relation to the study, it is shown that there is a higher interest in new discoveries and the well-being of society.

It is not necessary to fill students with a great deal of knowledge, from which few remain 
active, for study purposes. The right thing to do is to ensure that you have an adequate training in skills and abilities. Besides, it is important to teach them to think by themselves, how to manage information sources and give the students the conditions to appropriate independently of the essential knowledge. Platon (1966) states in his writings that "the emotional disposition of the student determines his capacity for learning" demonstrating the importance of emotions in the student body. Moreover, being motivated to study is essential because it allows you to obtain better results. If the personal and social motives are properly combined, it will be possible to develop greater efforts to learn. It is also possible to obtain attitudes and habits that have a positive influence on the practice of the future profession and on success as a worker.

\subsection{How to Learn to Study}

The Higher Education teacher must teach students how to learn to develop their skills, which is the achievement of the university teaching process (Tedesco \& Coll, 2009). One of these ways is the effort of university academics in the search, selection and adequate structuring of teaching content. In its broadest sense, it includes systems of knowledge, skills, convictions and abilities to acquire new knowledge by themselves and for the creative thinking. In this situation, the improvement of teaching methods and means is continuous, so that students assimilate the content of the teaching actively. This is evidenced by the possibility of being able to analyze, generalize and subsequently apply in a new situation (Delors, 1997).

\subsection{How students study}

Higher education students practice two essential models to learn. They can study individually and with another student in a group setting. According to Bruner (2000) there is a tendency to identify independent work as an individual study or an own preparation. However, these cannot be considered as synonyms.

Studying involves developing the skills that characterize being able to work independently. However, a student is capable of studying individually, when he is capable of performing cognitive activities without the direct guidance of the teacher-facilitator (Ferreiro, 1999). In addition, students can plan the study according to their needs. Also understand and manipulate the complexity of the tasks and the time available.

In the same way, the student knows what to do, they decide when, in what order and how to do it. The student organizes his work, and tries to ensure the necessary conditions to have everything in order to fulfill requirements. It requires guidance to work without being affected and without distractions that make it difficult for them to concentrate (Hopenhayn, 2002). According to the author who was cited before, students study in different ways. There are those who prefer to do it individually and thus make more use of their time. Instead, they sit down to study only when a friend forces them to do it. Both forms are valid, as long as at the end of the day you get an efficient learning of the proposed content as a product. To achieve optimal results in the study, it is necessary to select a suitable site. It is also necessary to have everything you need and to establish a schedule as organizational measures.

All of the above implies knowing how to decide what is needed or what should be studied at each moment by starting with the most pressing task and the most difficult content. With regard to individual study, students choose to apply the group learning technique.

Chehaybar and Kury (2012) define group learning as an indispensable production of the student, which encourages creativity, the development of new ideas and the transformation of the known ones. Therefore, information, emotion and production cannot be separated. Neither does active group work. For the author, the members of the group complement each other and gain a new experience, awakening interest in research and the common search for solutions to specific problems that lead to a transformation of reality.

In response to what was mentioned before, group or group study is carried out when a certain number of students meet to clarify any doubts that may arise after the class or in individual study. Students at the university level are often unable to fully understand the content they have studied. 
They always seek the help of another student they trust. Because in this way any doubt is cleared up on more than one occasion.

\subsection{Positive attitude towards Study}

In the new man formation process, it is very important to create a positive attitude towards study in the students. To achieve this, Bossolasco (2010) argues that it is necessary to know the role of attitudes. The governmental entities of university education in Ecuador maintain a constant concern in the formation of new generations. Likewise, the formation of the new man is a continuous and complex process (Perkins, 1996). According to this author, first of all, this process requires, full mastery of the educational objectives and a domain in each of the activities that are carried out. Secondly, it requires the knowledge of the qualities of the personality to be implemented and developed. Thirdly, it requires the knowledge of the characteristics of the students with whom the teacher works.

Attitudes occupy a prominent place for an integral knowledge of what personality is and how it develops. The higher education professor must have a constant analysis and evaluation of why a young person or adult acts in a particular way and not in another. Analyze and evaluate the outcome of a given behavior. Moreover, when the human being is a social being who is born lives and develops in society, he will form his attitudes according to the demands of the environment in which he develops. Also, the activities they carry out and the knowledge acquired in their interaction with them. All activities are described based on what society imposes on them.

Consequently, this study demonstrates a series of activities that favor the formation of positive attitudes towards the institution, study, work and society. However, sometimes this is achieved in one part of the group and not in the desired size. Some of the causes that do not allow the goal to be achieved in its entirety can be:

- Insufficient mastery of attitudes in personality development.

- The limited knowledge by the andragogic collective of the characteristics of the students.

- The carrying out of activities that do not favor the formation of positive attitudes towards study, work, society, among others.

\section{Methodology}

This study is part of the participatory action methodology. According to Colmenares (2012) it facilitates the integration of knowledge and action. It allows users to get involved, know, interpret and transform the reality under study. It favors actions that the professor proposes as alternative solutions to the problems identified. The author also states that the main interest is to generate definitive and deep changes and transformations.

Furthermore, the research is carried out by using this methodology, in order it possible to diagnose the problem in the academic field and propose a solution that benefits the teaching and learning process of UNIB.E. students. Its relevance lies in the use of guidelines to strengthen positive attitudes towards study as a necessary element for vocational training.

\subsection{Informants}

As informants, there are 22 students from the fourth semester of different careers who were selected in an intentional non-probabilistic way. According to the academic secretary, I report that the students were at the lowest levels of achievement. The observation guide is used to obtain the data. The survey is also used as a technique which is defined by Hernández et al., (2011) as a research instrument. The instrument consisted of obtaining information from the persons surveyed. Questionnaires were designed in advance to obtain specific information.

\section{Results and Discussion}

Once the research process on the situation had been applied, the following aspects were revealed according to the items of the instrument applied to the students. 


\subsection{According to item no. 1. What are your reasons for studying?}

The answers obtained showed that the participants study to obtain good grades. The students respond:

- I study to pass the semester.

- I study just enough to please my parents or relatives.

As described before, it can be seen that they have not formed adequate study habits or motivation. The results demonstrate the lack of reasons for undertaking the study. Not being seen as a relevant fact to learn significantly. These approaches lead to the conclusion that the conditions must be created for the student to value and assume positive attitudes towards study. Attitudes that can influence the exercise of their academic and professional development (Wertsch, 1998).

\subsection{Item 2. States what does it mean for you as a student to study?}

The researcher presents the different opinions of the students in a descriptive way, where the students respond:

- For us, studying has a great significance. Because through it we learn more every day and if we don't study enough tomorrow we will be nobody.

For other students, studying plays a fundamental role in the political and ideological formation of society. To study means to improve oneself, to know, to be able to work in the Republic of Ecuador for a better future.

They also responded that they would work to continue the development of learning. These answers give a conscious interpretation of the study. However, all the answers demonstrate the social need. Unfortunately, students do not always react as it was expected. There is concern among teachers that students are still not studying enough. They should also make better use of their time and study more.

\subsection{Item No. 3. What advantages will the study offer you?}

Among the most outstanding answers from the students surveyed they are:

- Studying encourages the habit of study. It makes us think. It makes us develop our thinking.

- The use of the book or the texts raises questions that do not arise at the class time.

- It offers the possibility of reaffirming the knowledge acquired in class. It offers the opportunity to deepen them with textbooks.

According to the answers given by the students it is considered that there are many advantages that can benefit the students' work. As long as the student assumes the importance of studying it is necessary to encourage students to become independent in the study.

The results show the need to promote the acquisition of knowledge in an organized, planned and systematic manner, develop a positive attitude towards the activity, prepare students for selfstudy and promote the acquisition of positive teaching habits, increase the possibilities of selfcontrol and regulation of cognitive activity, develop skills for independent work, consolidate what has been learned through the preparation of summaries and synoptic tables and promote the formation of cognitive interests.

\subsection{Item No. 4. What are the advantages of individual study for you?}

The students responded as follows:

- When I study alone, sometimes I'm faced with a question I can't answer.

- I stop with the book and search on the Internet.

- When I study alone, I don't have a habit, I waste a lot of time.

- I take care of other things.

- Studying individually seems boring and annoying to me. 
In relation to the answers issued by the majority of students similar study situations arise because there is not formation of habits to study. The teacher must be in alert, because of the need to study individually or in groups.

\subsection{Item No. 5. Do you like to study?}

The students' opinion is based on few studies. Among his most frequent opinions are:

- It's hard for me. It wears me out when I study.

This scenario shows that there is no initial training from childhood and adolescence that favors the habit of study. There may be no requirement on the part of the teacher to ensure satisfactory results with the study.

\subsection{Item No. 6. Do you have a study schedule?}

Most of the students responded:

- No, I don't have study hours.

- I study without planning.

- Many times I study to score well on an evaluation.

Students usually study at the last minute of the presentation. They do not pre-plan which generates low results, and leads to the fail of the subject. Subjects that are not learned with emotions are quickly forgotten. Studying without interest is only used for the time being.

\section{Conclusions}

According to the information obtained by the researcher the observation and the answers analyzed lead to the following conclusions:

- There are no programs to strengthen the study. In addition, there are no timely strategies to increase the degree of independence of investigations. It is not permitted to acquire knowledge in an organized, planned and systematic way. Students opt for group research.

- In such a way, that a positive attitude towards the fundamental activity, which study is not developed. There is also a lack of activities that encourage the acquisition of habits that allow the consolidation of what has been learned. Habits for dealing with doubts and maintaining the desire to learn more with fewer difficulties.

- The work of UNIB.E needs to be transformed so that students can actively participate in the study. It is considered necessary to resolve some difficulties and rejections of the academic system where many students meet and thus generate equal opportunities (National Plan of Good Living 2017-2021).

- The teacher must comply with an innovative andragogic practice, perform education by shaping teaching and learning strategies, applying critical and thoughtful knowledge encourages the student to develop activities that benefit the study and build tools that allow them to obtain meaningful learning and higher academic performance.

- To develop a model of Higher Education quality in order to strengthen student teaching and learning, positive attitudes toward study must be formed (Baxter, 2005). Positive attitudes are elements that guarantee a favorable interaction in learning.

- The change that must be generated involves looking after the learner as the subject of their own learning. This attention must be based on their own experience and heritage. It should also be understood that the projection of the study is elementary. Teaching must be strengthened in order to understand the context in which it takes place. It is essential to maintain the emotion, the affection and the desire to overcome. It is important not to subtract motivation from the fact that students are entering university for the first time.

- Based on the weaknesses found, a planning and implementation process was drafted. It is a series of guidelines to strengthen the student's attitude towards study. 


\subsection{Planning of transformative actions}

\subsubsection{Actions expressed and concretized}

\subsubsection{General objective:}

- To develop actions to strengthen positive attitudes towards the study.

\subsubsection{Specific objectives:}

- To sensitize students to the strengthening of attitudes towards study.

- To organize different spaces for the enjoyment of the study.

- To use strategies that encourage the student to study.

- To carry out actions that favors the acquisition of study habits.

\subsubsection{Activities:}

- Creation of study schedules

- Explanation of individual and collective study.

- Implementation of strategies.

- Activation

- Information Processing.

- Recapitulation of what is being studied.

- Reflection Strategy.

- Evaluation of the Processes

\subsubsection{Strategies:}

- Standard Setting

- Teamwork.

- Conversations

- Group Dynamics.

- Questions and Answers.

- Presentation of Cases

- Reflective Workshop

- Plenary

\subsubsection{Evaluation:}

- Observations

- Participation

- Development in the learning situation

- Academic performance

\subsubsection{Resources:}

- Humans: Students and Teachers

- Academic coordination

- Materials: Books, notebooks, ballpoint pen, pencil, teaching material, audiovisual projector, computer, internet, sheets of bond paper.

\subsubsection{Time:}

- 6 months 


\subsection{Implementation of transformative actions}

First, an awareness raising process is carried out which is an essential process to focus the answers searched on the objectives that were set. In addition, it is necessary to formulate common and shared criteria since the process to be carried out requires a necessary reflection to acquire individual and solidary commitments.

Activity $\mathrm{N}^{\circ}$ 1: Study schedules with students according to their needs and interests and availability of time. Then start with the learning actions developing in the different areas in reference to individual and collective study.

Activity 2: Explain what individual and collective study is.

First, formalize individual and group study groups. Then pose a series of questions and answers, to analyze and discuss the importance of ways to study. Next, deliver a text of any content for the student to select structure content and search for solutions. Identify whether students study or not a series of questions in which the following situations occur:

- Purpose of the information.

- Time spent.

- Effort made.

- Situations in which knowledge is mastered.

After, evaluating the activity in agreement with the students who study individually and after a discussion of points of view ask if they are studying to be informed or to be trained. In addition, to consolidate what has been learned, ask students to design a summary table and structural network. For group students, distribute several contents, analyze and draw conclusions. Then evaluate the process and confirm that all students work collaboratively.

Discuss the issues with each of the group members. Analyze which students contribute new ideas. Finally, conduct a self-assessment and a co-assessment.

Activity 3: Activation Strategy. This strategy is considered essential to strengthen the interest in the study and supports communication with the learning subject. Besides, it allows to call the attention and to activate their mind operation processes with an educational intention that was proposed previously.

To develop this strategy, a dynamic called murmuring is used, as follows:

A message is delivered to the individual students who work individually. Another message is then delivered to the group of students. Then they must exchange messages spontaneously. Once this contact is experienced, an exchange is made to identify those who agree with the answers. To evaluate the experience, attitudinal skills developed by students are considered.

In the same way, so that the student learn to read, in addition to strengthening the degree of comprehension it is used the technique called the wall phrase, which consists of writing on a sheet of paper a short message alluding to contents on the history of Ecuador.

Then instruct students to read carefully. Next, think for a minute and express opinions, views and comments on the approach. As the student think, place symphonic melodies by Vivaldi, Bach, Chopin, and Strauss used to achieve an alpha level of cortical activity. Studying facilitates an optimal focusing on attention (Marenco et al, 2015).

Then before the students ask for the highest attention there must not be interruption and accept all the criteria. In order to evaluate, different questions are asked, such as:

- What makes you think that?

The following process for developing the activation strategy is minimally perceptible. Teachers prompt students to listen to a reading in a minimum of ten minutes and a maximum of twenty minutes. This technique is applied with the intention of provoking reflection, first to those who work individually and then to the group of students. This action creates a socio-cognitive crisis in the students. It creates a conflict over the veracity of an approach. Through reading, the student assumes and expresses what he or she understands. The student also identifies what he or she wants to express. To evaluate the activity, conclusions are drawn from the consensus reading.

To promote interest in the study, it is used a reference list, it is checklist to make them think about where to get information. For the evaluation, different topics are identified in the framework. 
Then the abstract technique is practiced. Giving the students a topic and a summary of the most relevant aspects to evaluate this activity by writing everything in a portfolio that allows students to improve the aspects described.

Activity 4: Information processing strategy. This technique allows to know the reality to strengthen the learning process. Furthermore, it allows to understand the reality and nature of the study. It consists of the sequence of interrupted actions that allow students to capture and select stimuli of different types so that they can be processed according to their needs and interests. Then they should understand what they are studying and how they should do it.

Students are asked to take notes, to write down what they hear, read or observe. They write down the most important things they hear, read and observe, ignoring the distractors. Learning according to this activity allows students to show better attention, vocabulary enrichment and recording of the most important things.

The preparation of files to process the information and record the most significant data from the source of consultation as a manuscript is structured as follows:

- Underline important terms and words

- List the manuscript.

- Give a logical order and a way of thinking.

- Important words can be found in the dictionary, in books or on the Internet.

- So there are words whose meaning you don't know.

- Make personal comments and impressions.

- Underline the concepts of the topic; establish relationships between topics and concepts.

- Create structural networks, develop questions and provide answers.

- Apply analogies between what is studied and what is known

- Express with images the most significant aspects of the contents.

To evaluate this activity, students are asked to develop an organizer of ideas about the information processed. Then share those who work individually and in groups. The teacher should develop an assessment instrument with the questions:

- What did you know about it before?

- What did you learn?

- How did you learn it?

- What difficulties did you have?

- How do you feel about information processing?

Activity No. 5: A strategy to summarize what is being studied. For the development of this activity, they are used didactic tools, through images and scientific words such as word searches, crossword puzzles and drawings. The learning is acquired in a short time, allowing a better understanding. It allows students to systematize what they were learning by requesting symbolic representation of complex concepts.

Activity No. 6: Reflection strategy. It is applied as a technique to demonstrate the meaning of studying and learning, such as: writing everyday life problems. Then videos are shown to ask students to make predictions.

- The teacher will ask you what this tittle suggests.

- What do you think this is about?

- Why do you think that it is like is?

The teacher can evaluate the cognitive capacity of the student, through their emotional logic.

\subsection{Systematization of Research}

The guidelines are found in reference to assuming positive attitudes towards the study. It is considered an elementary action for the integral development of the university student. These were exceeded according to the planning and execution of activities. It was developed within a framework of participation and motivation that allows for great changes in the vision of the students for their respective studies. The actions are easy to apply. It also expresses a feeling of being linked in a different way to everyday education. Students can contribute elements that generate 
changes in the andragogic practice and in the classroom actions. A shared commitment can be made between the research professor and the students. A flexible work and research space is opened up for the training of the activities to be developed.

It is important to maintain continuous motivation, seek greater academic results in the short term where the valuable contribution of each of those involved is recognized. The experience applied by the students gives a way to work that offers an integrated andragogic framework. The union between the different actors of the university educational process, student-academia and society must be valued. The student must assume the dialogue, the confrontation of experiences and actions from the classroom to society. The student should be involved in a participatory study, as an alternative, mediator of formative processes.

The proposed process opens up expectations for strengthening group study according to the students selected. The feasibility of applying these processes to all students is demonstrated in order to guarantee the continuity of this experience; situations are promoted to maintain the motivation of the participating students. Studies should be evaluated to strengthen and provide feedback on aspects that have weaknesses. In the university, different activities should be created to encourage interest in study and to create greater reliability.

\subsection{Recommendations}

At the conclusion of the study, it is recommended:

- To encourage students to reflect and motivate themselves about the new transformations, in order to maintain their interest and be able to assume positive attitudes towards university studies.

- Exchange experiences with other careers and semesters, to verify the effectiveness of the processes. Allow students to demonstrate their skills in order to maintain motivation. Strengthen the necessary elements that make it difficult for students to work in terms of how to study.

- Apply systematic follow-up, as a motivational dynamic, to create a climate of trust, openness and active participation to generate expectations of attitudinal support in the students and promote the development of the reading habit.

- To open a space where students can exchange experiences through different strategies in order to favor the affirmation and expansion of the personality of the being, its needs, motivations and interests.

- Incorporate actions for the creation of study groups that strengthen teaching and learning, to achieve greater academic performance.

\section{References}

Abero, L., Berardi, L., Capocasale, A., García, S., \& Rojas, R. (2015). Investigación Educativa: Abriendo puertas al conocimiento. Montevideo: Contexto S.R.L.

Baxter, P. (2005). El Estudio Individual o Colectivo. La Habana: Pueblo y Educación.

Bossolasco, M. (2010). El foro de discusión - entorno mediado para la mediación cognitiva. Mendoza: Editorial Virtual Argentina.

Bruner, J. (2000). Globalización y el futuro de la educación: tendencias, desafíos, estrategias. Santiago de Chile: OREALC.

Bruns, B. \& Luque, J. (2014). Profesores excelentes: Cómo mejorar el aprendizaje en América Latina y el Caribe. Washington: Grupo del banco mundial.

Chehaybar, E. \& Kury (2012). Técnicas para el aprendizaje grupal: Grupos numerosos. México: IISUE.

Colmenares, A. (2012). Investigación-acción participativa: una metodología integradora del conocimiento y la acción. Revista Latinoamericana de Educación Voces y Silencios, 3, 1, 102-115.

Dalmau M. Guasch, D., Sala, I., Llinares, M., Dotras, P., Álvarez, M. \& Giné, C. (2002). Diseño Universal para la Instrucción (DUI): Indicadores para su implementación en el ámbito universitario. Barcelona: Universidad Ramón Llull.

Delors, J. (1997). La educación encierra un tesoro. México: Correo de la UNESCO.

Ferreiro, E. (1999). Cultura escrita y educación. México: Fondo de cultura económica. 
Hernández, García, López \& Rodríguez (2011), Estudio de encuestas. Métodos de Investigación. [On line] Available:https://www.uam.es/personal_pdi/stmaria/jmurillo/InvestigacionEE/Presentaciones/Curso_10/E NCUESTA_Trabajo.pdf (January 4, 2018).

Hopenhayn, M. (2002). Educar para la sociedad de la información y de la comunicación: una perspectiva latinoamericana. Revista Iberoamericana de Educación, 30(4), 187-217.

López, N. (2009). Las metas educativas ante el nuevo panorama social y cultural de América Latina. Calidad, equidad y reformas en la enseñanza. Madrid: OEI.

Llorens, F. (2013) Tendencias Universidad: En pos de la educación activa. Madrid: Cátedra UNESCO de Gestión y Política Universitaria.

Marenco, F., Mirón, V., Molina, D., Ortega, F. \& Rodríguez, L. (2015). Influencia de la música en la concentración. [Online] Available: http://www.ujmd.edu.sv/images/PDF/Contenido_/revistas/Boletin_Psique_Mayo_2015.pdf (January 5, 2018)

Mendoza, D. (2018). Estrategias didácticas para el fortalecimiento del proceso lector a nivel andragógico. Innova Research Journal, 3(3), 35-52.

Otxandorena, M. (2010), Trabajo de Evaluación de Tercer Curso de Terapia Familiar, Escuela Vasco Navarra de Terapia Familiar. [On line] Available: http://www.avntf-evntf.com/wp-content/uploads/2016/11/OtxandorenaM.-Trab.-3\%C2\%BA-semip.-09.pdf (January 2, 2018)

Perkins, D. (1996) La escuela inteligente. Barcelona: Gedisa.

Platón, (1966) Obras Completas. Madrid: Aguilar.

Rodríguez, J., Dalmau, J., Pérez, B., Gargallo, E. \& Rodríguez, G. (2014). Educar para Emprender. España: Universidad de La Rioja, Servicio de Publicaciones.

Rossi, R. (2014). A-Educación o Educación: Lo que todo educador sabe pero no se anima a practicar. Argentina: Autoedición.

Tedesco, J. \& Coll, C. (2009). Calidad, equidad y reformas en la enseñanza. Madrid: OEI.

Wertsch, J. (1998). Vigotsky y la formación social de la mente. Buenos Aires: Paidós. 